$\S=$ 原

\title{
Zinc, a micronutrient and its effect to performance of BARI gom30
}

\author{
Salamun Gismy ${ }^{1}$, Md. Romij Uddin ${ }^{2}$, Md. Sohanur Rahman ${ }^{3}$, Fakhar Uddin \\ Talukder $^{3}$, Md. Shafiul Islam Rion ${ }^{4}$ \\ ${ }^{1}$ Department of Agronomy, Bangladesh Agricultural University, Mymensingh-2202, Bangladesh \\ ${ }^{2}$ Professor, Department of Agronomy, Bangladesh Agricultural University, Bangladesh \\ ${ }^{3}$ Scientific Officer, Pest Management Division, Bangladesh Jute Research Institute, Bangladesh \\ ${ }^{4}$ Department of Agricultural Chemistry, Bangladesh Agricultural University, Mymensingh-2202, Bangladesh
}

*Corresponding author E-mail: sohanbau2010@gmail.com

\begin{abstract}
To evaluate the effect of Zinc fertilizer on performance of wheat cv. BARI gom30, an experiment was carried out at Agronomy Field Laboratory, Bangladesh Agricultural University, Mymensingh, from November 2015 to March 2016. The experiment comprised four levels of Zinc (Zn) viz., 0, 1.5, 2 and $2.5 \mathrm{~kg} / \mathrm{ha}$. The experiment was laid out in a randomized complete block design with three replications. Application of Zinc (Zn) plant height, number of total tillers/plant, number of effective tillers/plant, spike length, number of fertile spikelets/spike numbers of sterile spikelets/spike number of grains/ spike, grain yield and straw yield were found significant. But there was no significant effect of the treatment on 1000-grain weight. The highest number of total tiller/plant (4.42), number of effective tillers/plant (3.92), number of grains/spike (47.70), 1000-grain weight (47.73 g), grain yield (5.06 t/ha), straw yield (6.21 t/ha) was obtained from $2 \mathrm{~kg} \mathrm{Zn/ha.} \mathrm{The} \mathrm{highest} \mathrm{plant} \mathrm{height}(94.08 \mathrm{~cm})$, spike length $(9.92 \mathrm{~cm})$, number of fertile spikelets/spike (19.59) and sterile spikelets/spike (3.22) and harvest index (46.16\%) were recorded at $0 \mathrm{~kg} \mathrm{Zn/ha}$ respectively. The control treatment indicated the lowest value for the yield attributing characters except the number of sterile spikelets/spike. Grain yield was found to be significantly and positively correlated with number of grains/spike and straw yield. It is recommended that application of $2 \mathrm{~kg} \mathrm{Zn} / \mathrm{ha}$ is the best for maximum yield of BARI gom 30 .
\end{abstract}

Keywords: Zinc; Yield Contributing Characters; BARI Gom30.

\section{Introduction}

Wheat (Triticum aestivum L.) is the most important cereal crop of the world. It ranks first both in area and production. About one third of the total population of the world live on it. Wheat is the second staple food in Bangladesh. Wheat contains $12.1 \%$ protein compared to $8.29 \%$ in rice.

$\mathrm{Zn}$ is a micronutrient which is required for plant growth relatively in a small amount. Zn deficiency is one of the most wide spread limiting factors to crop production. $\mathrm{Zn}$ is an essential element required by all plants as it is a critical component of many enzymes and proteins. Zinc is an important essential element present in plant enzymatic systems. The integrity of cellular membranes also requires $\mathrm{Zn}$ to preserve the structural orientation of macro molecules and keep ion transport system Chauhan et al. (2014).

Zn contributed in photosynthesis, chlorophyll, metabolism of starch formation and enzyme carbonic anhydrase accelerating carbohydrate formation, the maximum requirements $\mathrm{Zn}$ were enough to accumulate suitable carbohydrate contents. It also activate glutamic dehydrogenase enzyme, synthesis of RNA and DNA enhancing gliadin and glutenin content, which are main protein components of gluten accumulated in the later stages of grain filling. The results are in conformity with the findings of Singh (2002), Seadh et al. (2009) and Soleimani and Shahrajabian (2012).

Ranjbar and Bahmaniar (2007) conducted an experiment in order to investigate the role of $\mathrm{Zn}$ application (soil + foliar application) on growth traits, yield, its concentration and accumulation in wheat leaves and grains, two common cultivars of wheat namely Tajan and Nye 60 have been selected. Four Zn fertilizer levels including $\mathrm{Zn}_{0}$ (no zinc fertilizer), $\mathrm{Zn}_{1}(5 \mathrm{~kg} \mathrm{Zn} / \mathrm{ha}$ in soil $+300 \mathrm{~g} \mathrm{Zn} / \mathrm{ha}$ in foliar application), $\mathrm{Zn}_{2}\left(10 \mathrm{~kg} \mathrm{Zn} / \mathrm{ha}\right.$ in soil $+600 \mathrm{~g} \mathrm{Zn} / \mathrm{ha}$ in foliar application) and $\mathrm{Zn}_{3}(15 \mathrm{~kg} \mathrm{Zn} / \mathrm{ha}$ in soil $+900 \mathrm{~g} \mathrm{Zn} / \mathrm{ha}$ in foliar application) both from $\mathrm{ZnSO}_{4}$ source have been applied in planting and booting stage in soil and as foliar application. Zn had increasing effects on grain yield, total dry matter, yield, 1000 grain weight, number of tiller, grain $\mathrm{Zn}$ content, flag leaf $\mathrm{Zn}$ content, plant height, number of node, protein content and grain Fe content.

$\mathrm{Zn}$ is known to have an important role either as a metal component of enzymes or as a functional, structural or regulatory co-factor of a large number of enzymes (Grotz and Guerinot, 2006).

Genc et al. (2006) reported that zinc has vast numbers of functions in plant metabolism and consequently zinc deficiency has a multitude of effects on plant growth. Zinc sulphate increased the leaf area index, the total number of fertile tillers $/ \mathrm{m}^{2}$, number of spikelets $/ \mathrm{spike}$, 
spike length, grain/spike, thousand grain weight, grain yield, straw yield and biological yield and decreased harvest index. All applications of zinc sulphate gave economic increases in margins over costs but the application of $5 \mathrm{~kg} / \mathrm{ha}$ gave the highest marginal rate of return.

Seilsepour (2006) conducted an experiment to optimize consumption of Zinc and evaluate of Zinc effects on quantitative and qualitative traits of winter wheat under saline soil condition and found that use of $80 \mathrm{Kg} / \mathrm{ha} \mathrm{Zn}$ as $\mathrm{ZnSO}_{4}$ in soil was recommended to obtain highest grain yield with high quality in saline condition.

Zinc has been found useful in improving yield and yield components of wheat (Cakmak et al., 1996; Modaihsh, 1997; Kaya et al., 2002; Singh 2004) and adequately applied zinc has been shown to improve the water use efficiency of wheat plants (Bagci et al., 2007).

The variations in number of tillers per hill, panicle length, weight of 1000 grains, yields of grain and straw, zinc concentrations and zinc uptake by grain and straw and zinc concentrations both pre-sowing and post-harvest soils clearly indicated that the native zinc concentration influenced them greatly and the variations were different in different locations. The nature of vegetations was also influenced by application. In order to obtain an optimum production and quality crops application of zinc with other nutrients should be advised particularly for wheat cultivation (Riffat et al., 2007).

The effects of zinc on the yield and yield components of wheat cv. Kiziltan-91 were determined in a field experiment conducted in Ankara, Turkey during 1998-2000. Zinc application increased the grain yield, number of seeds per spike and seed weight per spike of the crop (Atak et al., 2004).

$\mathrm{Zn}$ supply is considered as an important factor in reproduction process. According to Brown et al. (1993) formation of male and female reproductive organs and pollination process are disturbed in $\mathrm{Zn}$ deficiency which may be attributed to the reduction of Indol acetic acid (IAA) synthesis.

Grain sterility is one of the serious problems in obtaining higher yield of wheat in Bangladesh. Among different micronutrient elements, $\mathrm{Zn}$ is considered to be the most important which reduces the grain sterility and improves the grain quality. Zinc plays an important role in completing the life cycle of plants and also a key role in nitrogen metabolism, photosynthesis and toxin synthesis.

Nutrient deficiency is one of the important yield limiting factors viz. delayed sowing, high weeds infestations, water shortage at critical growth stages, intensive cultivation and imbalance and non-judicious fertilizers use. Deficiency of and response to zinc in wheat have been reported from various zones of the world. Bangladesh soils are not an exception to this. Zinc, a micronutrient element, is required for plant growth relatively to a smaller amount. The total zinc content of soil ranges from less than $10 \mathrm{ppm}$ to $1000 \mathrm{ppm}$. The functional role of zinc includes auxin metabolism in plants.

The increase in grain and straw yields as well as harvest index due to $\mathrm{Zn}$ fertilization might be due to the fact that $\mathrm{Zn}$ plays an important role in biosynthesis of IAA. Initiation of primordial structures at reproductive phase occurs as a result of favourable effect of zinc on the metabolic reactions within the plants. So it should be used in correct doses for increasing soil fertility and to boost crop yield. Considering the above importance of $\mathrm{Zn}$ in wheat cultivation, the research work was undertaken to examine the effect of $\mathrm{Zn}$ micronutrient on the performance of BARI gom30.

\section{Materials and methods}

The experiment was conducted at the Agronomy Field Laboratory, Bangladesh Agricultural University, Mymensingh during the period from November 2015 to March 2016 to investigate the effect of different levels of $\mathrm{Zn}$ on the yield performance of wheat. The experimental site belongs to the 'Old Brahmaputra Floodplain' under Agro Ecological Zone-09 (UNDP and FAO, 1988). The topography of the experimental plot was a medium high land which belongs to the 'Sonatola' series under the General Soil Type, Non-calcareous dark grey floodplain soils. Soil $\mathrm{pH}$ was 6.7 . Zinc value was $10.35 \mathrm{ppm}$.

\subsection{Description of the planting material}

Wheat variety "BARI Gom30" was used as plant material. BARI developed this variety and released in 2014. It is a most popular variety now due to its high yielding potentials and suitable for late planting after harvesting Aman rice. This variety attains a height of 95-100 $\mathrm{cm}$ and takes 100-105 days to complete its life cycle. It is a short duration variety and resistant to leaf blight and leaf rust disease. It is also a heat tolerant variety. The numbers of tillers/plant are 4-6 and the leaves are wide and deep green in color. It requires 60-65 days to heading. Grains are white, light and middle in size. Its yield is $4.5-5.5 \mathrm{t} / \mathrm{ha}$ and 1000 grain weight is $44-48 \mathrm{~g}$.

\subsection{Treatments}

The experiment consisted of the following treatments:

Zinc Dose (Zn)

i) $\quad 0 \mathrm{~kg} \mathrm{Zn} / \mathrm{ha}\left(\mathrm{Zn}_{0}\right)$

ii) $\quad 1.5 \mathrm{~kg} \mathrm{Zn} / \mathrm{ha}\left(\mathrm{Zn}_{1}\right)$

iii) $\quad 2 \mathrm{~kg} \mathrm{Zn} / \mathrm{ha}\left(\mathrm{Zn}_{2}\right)$

iv) $\quad 2.5 \mathrm{~kg} \mathrm{Zn} / \mathrm{ha}\left(\mathrm{Zn}_{3}\right)$

\subsection{Experimental design}

The experiment was laid out in a randomized complete block design with three replications; each representing a block. Each block was divided into 16 unit plots where 16 treatment combinations were allocated at random. The total number of unit plots in the experiment was $(16 \times 3) 48$. The size of each plot was $4.0 \mathrm{~m} \times 2.5 \mathrm{~m}$. Inter block and inter plot spacing were $1 \mathrm{~m}$ and $0.5 \mathrm{~m}$, respectively.

\subsection{Data collection techniques}

\subsubsection{Plant height}

Plant height was measured from the ground level to the tip of the uppermost spike lets of the panicle and their average was calculated. 


\subsubsection{Number of total tillers/ plant}

Number of total tillers/plant from each plot was counted from ten sample plants one week before harvest and their averages were taken.

\subsubsection{Number of effective tillers/ plant}

Number of effective tillers/plant from each plot was counted from ten plants one week before harvest and their average was taken.

\subsubsection{Length of spike}

Length of spike was measured from the sample plants and their averages were calculated.

\subsubsection{Number of spikelets/spike}

Number of spikelets/spike was counted taking ten spikes from the ten selected plants of each plot and the average number was recorded.

\subsubsection{Number of grains/spike}

Number of grains/spike was counted taking ten spikes from the sample plants of each plot and the average number was recorded.

\subsubsection{Number of sterile spikelets/spike}

Number of sterile spikelets/spike was counted taking ten spikes from the ten selected plants of each plot and the averages were recorded.

\subsubsection{Thousand grain weight (g)}

The weight of 1000 seeds from each plot was measured in gram taking ten plants at random from each unit plot.

\subsubsection{Grain yield (t/ha)}

Grains obtained from each unit plot were sun dried and weighed carefully. The dry weight of grains of selected plants was added to the respective unit plot to record the final yield/plot. The grain yield was finally converted to t/ha.

\subsubsection{Straw yield (t/ha)}

Straw obtained from each unit plot including the straw of sample plants of respective unit plot was dried in sun and weighed to record the final straw yield/plot and finally converted to t/ha.

\subsubsection{Biological yield (t/ha)}

Total weight of aerial biomass (including the grain) at maturity was measured from $10 \mathrm{~m}^{2}$ area of each plot and expressed as t/ha.

\subsubsection{Harvest index}

The harvest index was calculated as follows: Biological yield $=$ Grain yield + Straw yield

Harvest index $(\%)=\frac{\text { Grain yield }}{\text { Biological yield }} \times 100$

\subsection{Statistical analysis}

The collected data were analyzed statistically using the analysis of variance (ANOVA) technique and significances of mean differences were adjudged by Duncans New Multiple Range Test (Zaman et al., 1982).

\section{Results and discussion}

A field experiment was carried out to study the effect of $\mathrm{Zn}$ fertilizer application on the yield of wheat (cv. BARI Ghom30) including yield contributing characters. The effect of Nitrogen $(\mathrm{N})$ on yield and yield contributing characters of wheat have been presented below.

\subsection{Plant height}

Application of different levels of zinc influenced plant height significantly. The maximum plant height $(94.17 \mathrm{~cm})$ was found when the crop was fertilized with $2 \mathrm{~kg} \mathrm{Zn/ha}\left(\mathrm{Zn}_{2}\right)$ and the shortest plant height $(88.45 \mathrm{~cm})$ was from control (Figure 1). Above findings shown that plant height was greatly affected by $\mathrm{Zn}$ application. This result is strongly supported by Ananda and Patil, (2007). Several researchers reported that by application of $6 \mathrm{~kg} \mathrm{Zn/ha} \mathrm{than} \mathrm{other} \mathrm{lower} \mathrm{doses,} \mathrm{plant} \mathrm{height} \mathrm{increased} \mathrm{significantly} \mathrm{(Genc} \mathrm{et} \mathrm{al.,2006;} \mathrm{Jain} \mathrm{and} \mathrm{Da-}$ hama, 2006). 


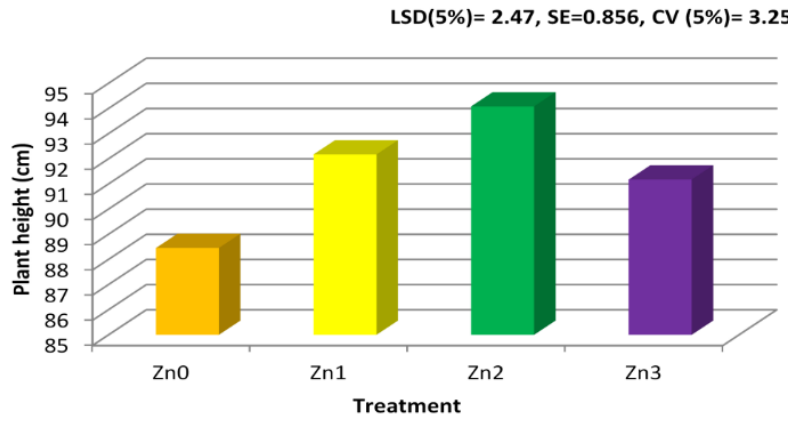

Fig. 1: Effect of Zinc on Plant Height (Cm).

\subsection{Number of total tillers/ plant}

Application of $\mathrm{Zn}$ significantly affected the total number of tillers/plant.The maximum number of total tillers/plant (4.42) was obtained from $2 \mathrm{~kg} \mathrm{Zn} / \mathrm{ha}\left(\mathrm{Zn}_{2}\right)$ and the minimum number of total tillers/plant (3.33) was from control (Figure 2). Similar results were also published by Prasad et al. (1981). Other researchers reported that number of total tillers/plant increased significantly by application of $6 \mathrm{~kg}$ Zn/ha than other lower doses (Dewal and Pareek, 2004 and Singh, 2004).

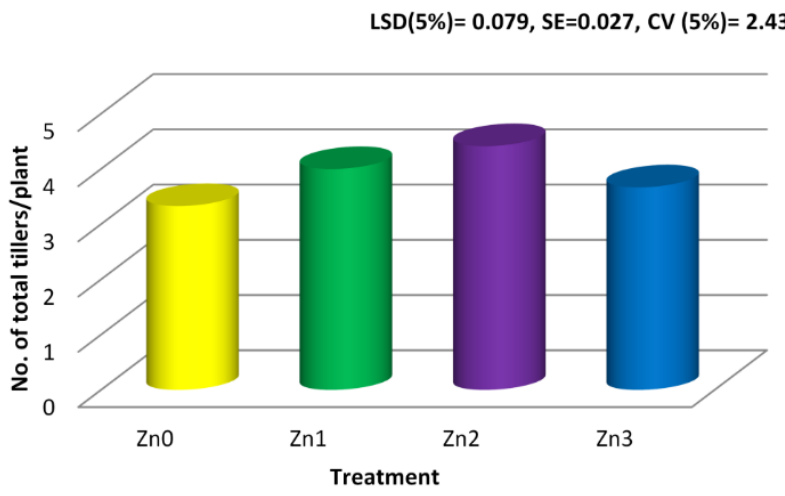

Fig. 2: Effect of Zinc on Total No. of Tillers/Plant.

\subsection{Spike length $(\mathrm{cm})$}

Different levels of Zn fertilizer was significantly affected the length of spike (Appendix III). Spike length increased with the increasing rates of $\mathrm{Zn}$ up to $2 \mathrm{~kg} \mathrm{Zn} / \mathrm{ha}$. The longest spike length $\left(9.92 \mathrm{~cm}\right.$ ) was obtained from $2 \mathrm{~kg} \mathrm{Zn} / \mathrm{ha}$ ( $\mathrm{Zn}_{2}$ ) (Figure 3). Jain and Dahama (2006) have reported that application of $6 \mathrm{~kg} \mathrm{Zn} /$ ha significantly increased all the growth and yield attributes. Zinc application improved spike length and effective tillers plant ${ }^{-1}$ (Islam et al., 1999).

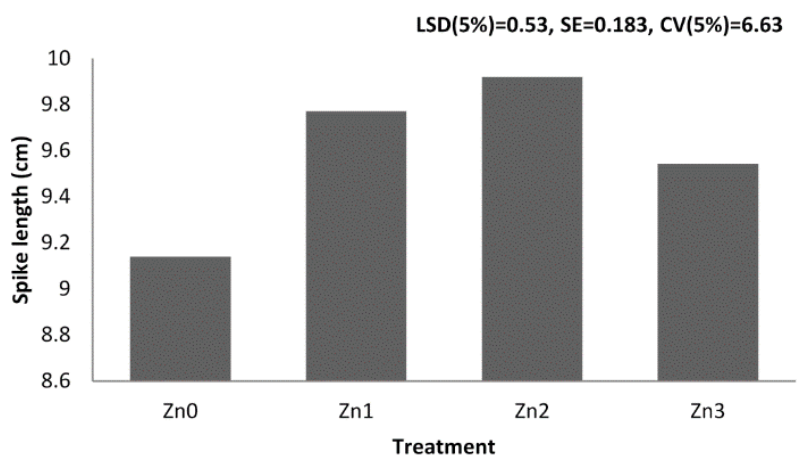

Fig. 3: Effect of Zinc on Spike Length (Cm).

\subsection{Number of effective tillers/ plant}

$\mathrm{Zn}$ had a significant effect on number of effective tillers/plant. The highest number of effective tillers/plant (3.76) was found when the crop was fertilized with $2 \mathrm{~kg} \mathrm{Zn} / \mathrm{ha}\left(\mathrm{Zn}_{2}\right)$ and the lowest (2.88) was recorded in control (Table 1). It can be concluded that increase in $\mathrm{Zn}$ levels caused considerable increase in number of effective tillers/plant. The positive effects of zinc application on effective tillers/plant of wheat were reported by Islam et al. (1999).

Table 1: Effect of Zinc on Number of Effective Tillers/ Plant

\begin{tabular}{ll}
\hline Level of nitrogen & Number of effective tillers/plant \\
\hline $\mathrm{Zn}_{0}$ & $2.83 \mathrm{~d}$ \\
$\mathrm{Zn}_{1}$ & $3.418 \mathrm{~b}$ \\
$\mathrm{Zn}_{2}$ & $3.918 \mathrm{a}$ \\
$\mathrm{Zn}$ & $3.000 \mathrm{c}$ \\
$\mathrm{LSD}_{0.05}$ & 0.126
\end{tabular}


SE

Level of significance

CV $(\%)$
0.043

**

4.64

\subsection{Number of fertile spikelets/ spike}

Number of fertile spikelets/spike of wheat also varied significantly due to the levels of $\mathrm{Zn}$ fertilizer. The highest number of fertile spikelets/spike (19.59) was observed in $2 \mathrm{~kg} \mathrm{Zn} / \mathrm{ha}\left(\mathrm{Zn}_{2}\right)$ treatment and the lowest number of fertile spikelets/spike (18.14) in control (Figure 4). In respect of number of fertile spikelets/spike $2 \mathrm{~kg} \mathrm{Zn}$ was the superior treatment among different levels of zinc, which was statistically identical with $1.5 \mathrm{~kg} \mathrm{Zn} / \mathrm{ha}$ (Fig. 4). Mahendra and Yadav (2006) revealed that application of increasing dose of $\mathrm{ZnSO}_{4}$ improved growth and yield parameters of wheat. Dewal and Pareek (2004) reported that the growth parameters, yield attributes, yield, net return and benefit: cost ratio increased significantly with application of $5 \mathrm{~kg} \mathrm{Zn} / \mathrm{ha}$.

$\operatorname{LSD}(5 \%)=1.07, \mathrm{SE}=0.37, \mathrm{CV}(5 \%)=6.82$

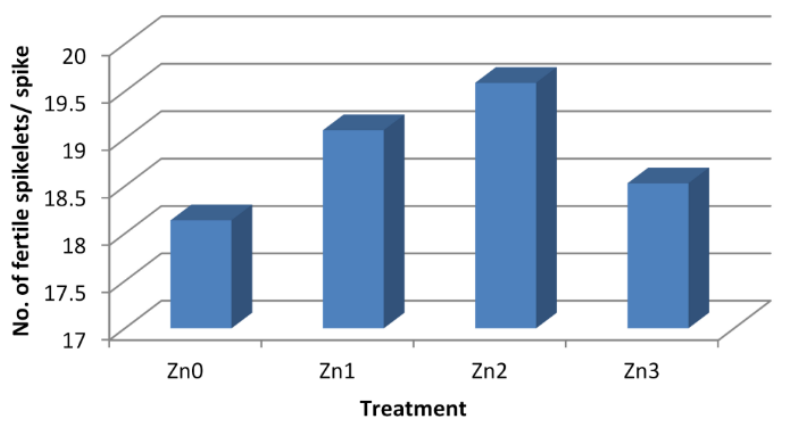

Fig. 4: Effect of Zinc on Number of Fertile Spikelets/ Spike.

\subsection{Number of sterile spikelets/ spike}

Results showed that the number of sterile spikelets/spike was significantly influenced by Zn fertilization. The highest number of sterile spikelets/spike was obtained from the control and the lowest (2.78) was found in $2 \mathrm{~kg} \mathrm{Zn} / \mathrm{ha}(\mathrm{Zn} 2)$ which was statistically identical with $1.5 \mathrm{~kg} \mathrm{Zn} / \mathrm{ha}$ (Figure 5). Razvi et al. (2005) reported that the soil application of $\mathrm{ZnSO}_{4}$ at $10 \mathrm{~kg} / \mathrm{ha}$ recorded significantly the lowest number of sterile spikelets/spike of wheat. It may be explained that the deficiency of $\mathrm{Zn}$ causes sterile spikelets/spike.

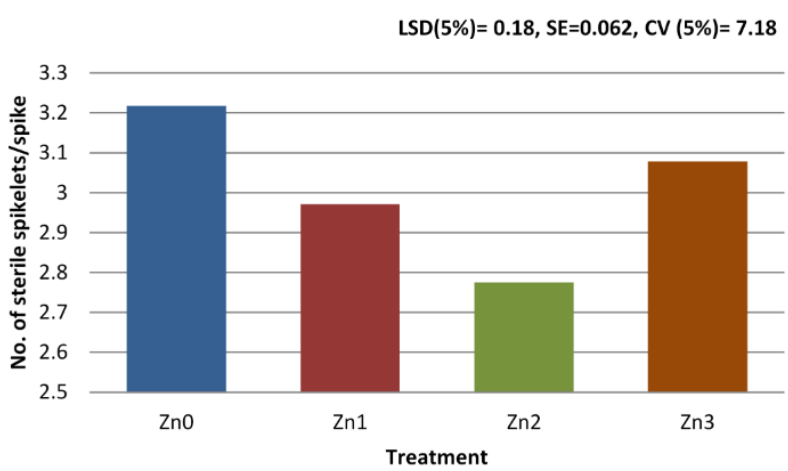

Fig. 5: Effect of Zinc on Sterile Spikelets/ Spike.

\subsection{Number of grains/ spike}

The influence of $\mathrm{Zn}$ on the number of grains/spike was statistically non-significant. Number of grains/spike increased with the increase of $\mathrm{Zn}$ up to $2 \mathrm{~kg} / \mathrm{ha}$. Number of grains/spike was highest (47.70) at $2 \mathrm{~kg} \mathrm{Zn} \mathrm{ha}\left(\mathrm{Zn}_{2}\right)$ and the lowest (45.47) was at control (Figure 6). The results are in conformity with that of Sundar et al. (2003) and Sundar and Choudhary (2002) who reported that $10 \mathrm{~kg} Z \mathrm{Zn} / \mathrm{ha}$ increased grain number/spike. Soleimani (2012) also reported that the number of grains/spike was increased for the application of zinc. Zinc application improved number of grains/plant (Genc et al., 2006).

$\operatorname{LSD}(5 \%)=1.3, \mathrm{SE}=0.45, \mathrm{CV}(5 \%)=3.36$

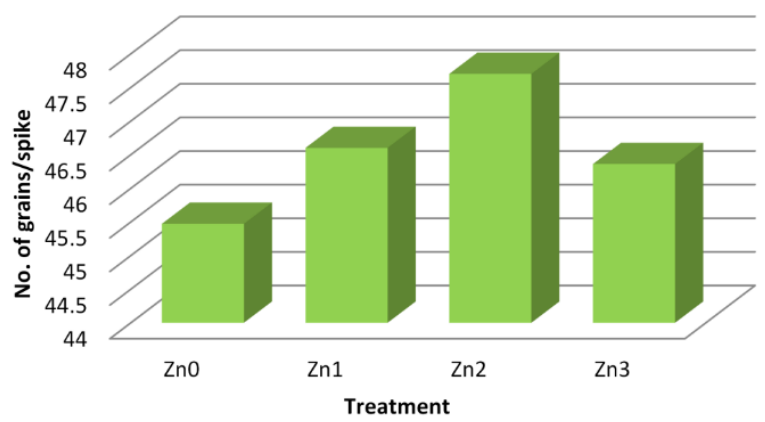

Fig. 6: Effect of Zinc on Grains/Spike. 


\subsection{0-grain weight}

Weight of 1000 grains was showed significant variation due to $\mathrm{Zn}$ application. The highest 1000 -grain weight (47.73 g) was found by applying $\mathrm{Zn}$ at the rate of $2 \mathrm{~kg} \mathrm{Zn} / \mathrm{ha}\left(\mathrm{Zn}_{2}\right)$ and the second highest 1000-grain weight $(46.59 \mathrm{~g})$ was found at $1.5 \mathrm{~kg} \mathrm{Zn} / \mathrm{ha}(\mathrm{Table} 2)$. Positive effects of $\mathrm{Zn}$ application on 1000-grain weight were also reported by Ananda and Patil (2007); Kenbaev and Sade (2002) and Hosseini (2006) reported that yield components increased with the increase in zinc rate. Jiang et al. (2013) indicated increment of 1000 grains weight in response of soil supplement of $\mathrm{Zn}$ at the rate of $200 \mathrm{mg} / \mathrm{kg}$ in the form of $\mathrm{ZnSO}_{4}$.

Table 2: Effect of Zinc on 1000-Grain Weight (Gm)

\begin{tabular}{ll} 
& Table 2: Effect of Zinc on 1000-Grain Weight $(\mathrm{Gm})$ \\
\hline Level of nitrogen & 1000 -grain weight $(\mathrm{gm})$ \\
\hline $\mathrm{Zn}_{0}$ & $45.36 \mathrm{~b}$ \\
$\mathrm{Zn}_{1}$ & $46.59 \mathrm{ab}$ \\
$\mathrm{Zn}_{2}$ & $47.73 \mathrm{a}$ \\
$\mathrm{Zn}_{3}$ & $46.33 \mathrm{ab}$ \\
$\mathrm{LSD}$ & 1.42 \\
$\mathrm{SE}$ & 0.492 \\
Level of significance & $* *$ \\
$\mathrm{CV}(\%)$ & 3.67 \\
\hline
\end{tabular}

\subsection{Grain yield (t/ha)}

Different $\mathrm{Zn}$ levels showed non-significant variations on grain yield of wheat. Among the treatments, $2 \mathrm{~kg} \mathrm{Zn} / \mathrm{ha}(\mathrm{Zn} 2) \mathrm{produced}$ the highest grain yield (5.06 t/ha) and the lowest (4.60 t/ha) was found from the control. The second highest was obtained from $1.5 \mathrm{~kg} \mathrm{Zn} / \mathrm{ha}$ (Figure 7). These results agree with Torun et al. (2001) and Grewal et al. (1997), who reported increased grain yield for zinc application. Many authors also showed that grain yield increased significantly with increasing Zn levels (El-Majid et al., 2000 and Seilsepour, 2007). Zinc application increased the grain yield, number of seeds per spike and seed weight per spike of the crop (Atak et al., 2004). Singh et al. (2012) also reported that increasing levels of zinc increased wheat yield.

$\operatorname{LSD}(5 \%)=083, \mathrm{SE}=0.029, \mathrm{CV}(5 \%)=2.03$

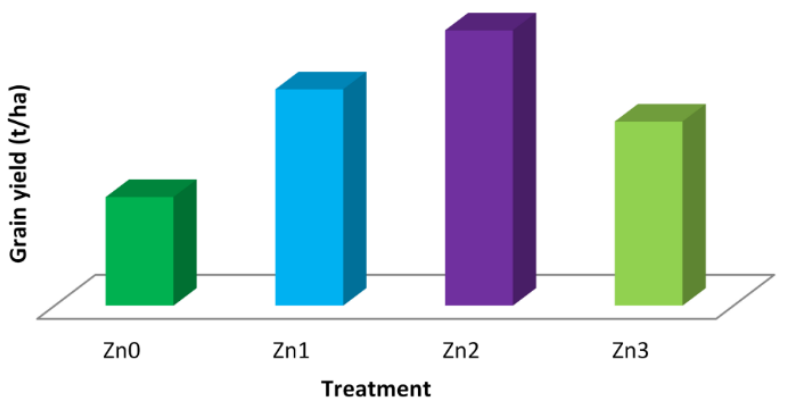

Fig. 7: Effect of Zinc on Grain Yield (T/HA).

\subsection{Straw yield}

$\mathrm{Zn}$ is an important essential element present in plant enzymatic systems. The effect of different doses of $\mathrm{Zn}$ also showed significant effect on straw yield. The production of highest straw yield was $(6.23 \mathrm{t} / \mathrm{ha})$ in $2 \mathrm{~kg} \mathrm{Zn} / \mathrm{ha}\left(\mathrm{Zn}_{2}\right)$ might be due to the fact that $\mathrm{Zn}$ tends primarily to encourage vegetative growth. The lowest straw yield $(5.37 \mathrm{t} / \mathrm{ha}$ ) was obtained from control treatment (Figure 8$)$. The findings for this character agree with the result obtained by Genc et al. (2006). However, Seilsepour (2007) reported that zinc sulfate had not any effects on straw yield of wheat. The results are in close conformity with findings of Goswami (2007).

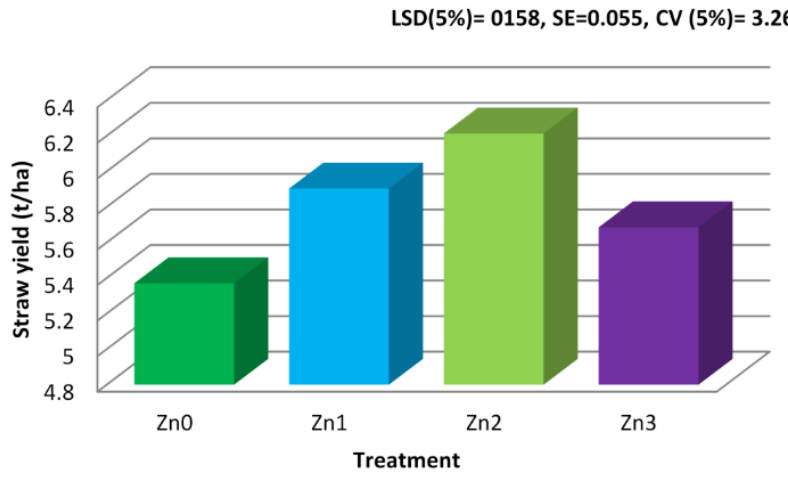

Fig. 8: Effect of Zinc on Straw Yield (T/HA).

\subsection{Biological yield}

Different $\mathrm{Zn}$ levels significantly influenced the biological yield of wheat. It was noted that biological yield is calculated from the total of grain yield and straw yield. The highest biological yield (11.27 t/ha) was obtained when the crop fertilized with $2 \mathrm{~kg} \mathrm{Zn} / \mathrm{ha}(\mathrm{Zn} 2)$ and the lowest (9.97 t/ha) was from control. These results indicated that increasing $\mathrm{Zn}$ levels from 0 to $2 \mathrm{~kg} \mathrm{Zn/ha} \mathrm{(Table} \mathrm{3).} \mathrm{It} \mathrm{is} \mathrm{evident} \mathrm{from}$ the results that $\mathrm{Zn}$ had remarkable influence on biological yield. $\mathrm{Zn}$ is an important element that present in plant enzymatic systems. Var- 
ious authors reported that biological yield of wheat increased with increased rate of Zn application (Ali et al., 2009 and Grewal et al., 1997).

Table 3: Effect of Zinc on Biological Yield (T/HA)

\begin{tabular}{ll}
\hline Level of Zinc & Biological yield (t/ha) \\
\hline $\mathrm{Zn}_{0}$ & $9.97 \mathrm{~d}$ \\
$\mathrm{Zn}_{1}$ & $10.80 \mathrm{~b}$ \\
$\mathrm{Zn}_{2}$ & $11.27 \mathrm{a}$ \\
$\mathrm{Zn}_{3}$ & $10.49 \mathrm{c}$ \\
$\mathrm{LSD}_{0.05}$ & 0.207 \\
$\mathrm{SE}$ & 0.072 \\
$\mathrm{Level} \mathrm{of} \mathrm{significance}$ & $* *$ \\
$\mathrm{CV}(\%)$ & 2.34 \\
\hline
\end{tabular}

\subsection{Harvest index}

The effects of $\mathrm{Zn}$ on harvest index showed significant variation. The highest harvest index (46.16\%) was observed under control and the lowest (44.88) from $2 \mathrm{~kg} \mathrm{Zn/ha}\left(\mathrm{Zn}_{2}\right)$ (Table 4). The second highest was obtained from $2.5 \mathrm{~kg} \mathrm{Zn} / \mathrm{ha}$. Khan et al. (2008) has reported that zinc applications actually decreased harvest index.

Table 4: Effect of Zinc on Harvest Index (\%)

\begin{tabular}{ll}
\hline Level of Zinc & Harvest index $(\%)$ \\
\hline $\mathrm{Zn}_{0}$ & $46.16 \mathrm{a}$ \\
$\mathrm{Zn}_{1}$ & $45.27 \mathrm{ab}$ \\
$\mathrm{Zn}_{2}$ & $44.88 \mathrm{~b}$ \\
$\mathrm{Zn}_{3}$ & $45.81 \mathrm{a}$ \\
$\mathrm{LSD}$ & 0.862 \\
$\mathrm{SE}$ & 0.298 \\
Level of significance & $*$ \\
$\mathrm{CV}(\%)$ & 2.28 \\
\hline
\end{tabular}

\subsection{Correlation and regression studies}

The degree of statistical relationship between grain yield and number of effective tillers/plant, grain yield and number of fertile spikelets/spike, grain yield and number of grains/spike, grain yield and straw yield of wheat has been found out significant relationship at $1 \%$ level of probability. The positive slopes exhibited positive relationship.

\subsubsection{Grain yield and number of effective tillers/ plant}

The degree of relationship between grain yield and number of effective tillers/plant of wheat was studied (Figure 9). The result revealed that grain yield and number of effective tillers/plant have a direct significant positive relationship at $1 \%$ level of significance which has been confirmed with correlation co-efficient $\mathrm{r}=0.949$ (Figure 9). The relationship was more evident by the equation $\mathrm{Y}=$ and sowing gradual $\mathrm{Y}=0.3759 \mathrm{x}+3.6046$ increase in grain yield with the increase of number of effective tiller/plant.

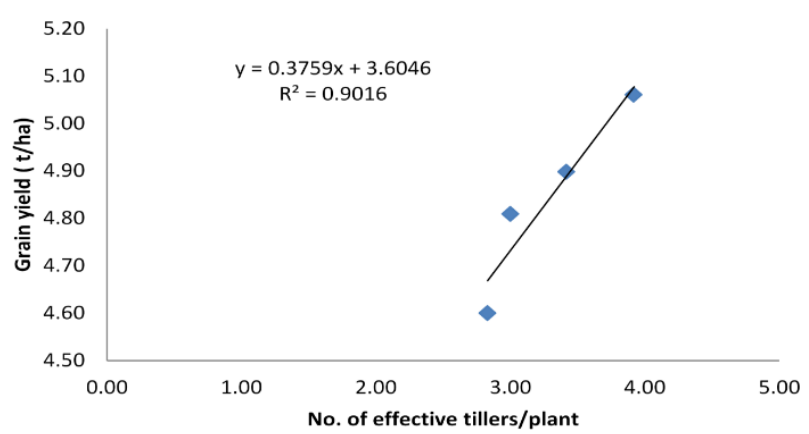

Fig. 9: Relation Between Grain Yield and No of Effective Tillers/Plant of Wheat Cv. BARI Gom30.

\subsubsection{Grain yield and number of fertile spikelets/spike}

A correlation matrix was done in order to observe the degree of interrelationship between grain yield and number of fertile spikelets/spike. The result showed that the grain yield and number of fertile spikelets/spike have a significant relationship at $1 \%$ level of significance. The correlation coefficient $\mathrm{r}=0.9772 * *$ (Figure 10) and the regression line of $\mathrm{Y}$ (grain yield) on $\mathrm{X}$ (number of fertile spikelets/spike) having the equation $\mathrm{Y}=0.2955 \mathrm{x}-0.7246$. The positive slope indicates that grain yield and number of fertile spikelets/spike are directly correlated, i.e. increase in number of fertile spikelets/spike. 


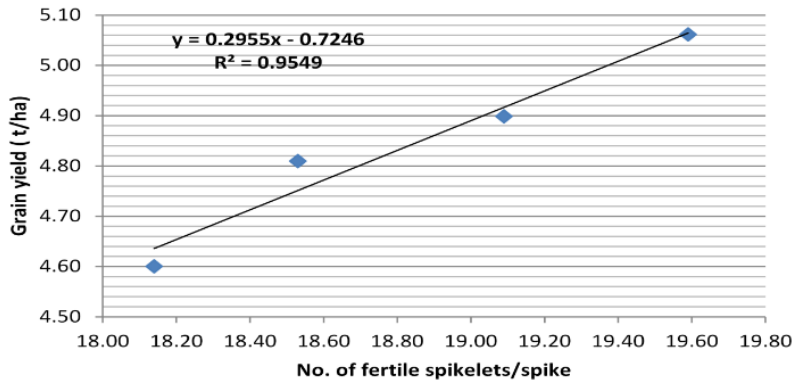

Fig. 10: Relation Between Grain Yield and Number of Fertile Spikelets/Spike of Wheat Cv. BARI Gom30.

\subsubsection{Grain yield and number of grains/ spikelet}

The degree of relationship between grain yield and number of grains/spike of wheat was studied (Figure 11). It is shown from the result that there was a direct significant and positive relationship at $1 \%$ level of significance between grain yield and number of grains/spike. The correlation co-efficient $\mathrm{r}=0.8397^{* *}$ and the regression line of y (grain yield) on number of grains/spike having $\mathrm{Y}=0.2855 \mathrm{x}-$ 8.3838. The positive slope indicates that grain yield and number of grains/spike are directly correlated, i.e. increase in number of grains/spike.

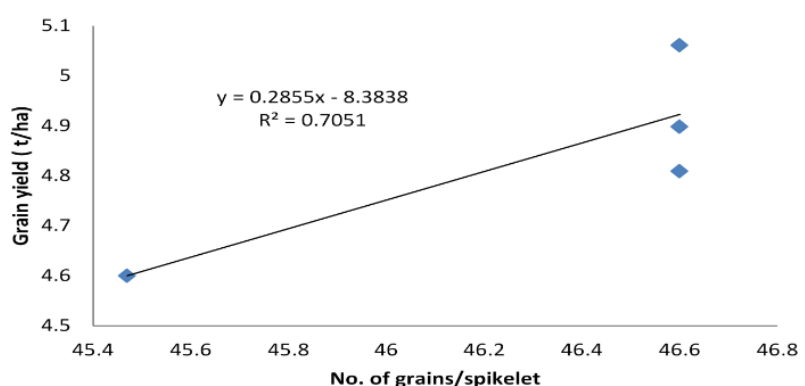

Fig.11: Relation Between Grain Yield and Number of Grains/Spikelet of Wheat Cv. BARI Gom30.

\subsubsection{Grain yield and straw yield}

From the results of experiment it is observed that grain yield showed significantly positive correlation with its straw yield $(\mathrm{r}=0.9959 * *)$. The regression equation of $\mathrm{Y}$ (grain yield) vs (straw yield) was found to be $\mathrm{Y}=0.5383 \mathrm{x}+1.7237$ (Figure 12). It means that an increase in straw yield will lead to an increase in grain yield.

The present experiment was undertaken with some objectives. The need of such a study under field conditions was justified by presenting and amplifying the review of literature. The overall results represented that the application of $\mathrm{N}$ and $\mathrm{Zn}$ played a significant role in efficient wheat production. The definite information from above discussion will be useful for national policy making to achieve optimum yield production of wheat in Bangladesh.

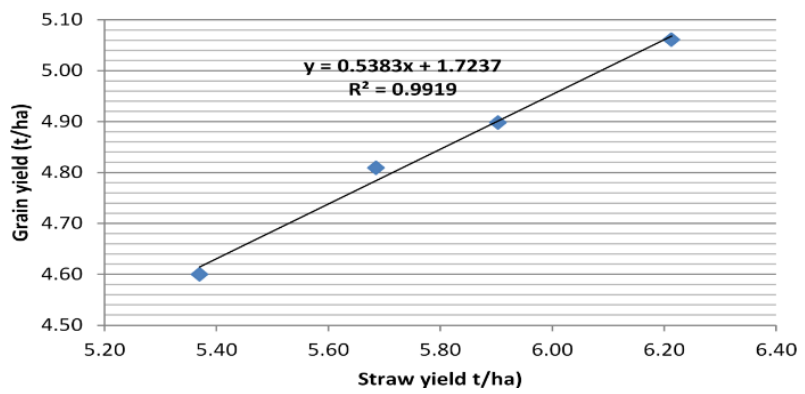

Fig. 12: Relation between Grain Yield and Straw Yield of Wheat Cv. BARI Gom30.

\section{Acknowledgement}

Authors are grateful to the Ministry of science and technology, Bangladesh for providing financial support to conduct the research work.

\section{Conflict of interest}

The authors have no conflict of interest to report.

\section{References}

[1] Ali S, Shah A, Arif M, Miraj G, Ali I, Sajjad M, Farhatullah MY, Khan and Khan, NM (2009) Enhancement of wheat grain yield and yield components through foliar application of Zinc and Boron.Sarhad J. Agric. 25(1), 15-19.

[2] Ananda N and Patil BN (2007) Effect of zinc, iron and split application of nitrogen on growth, yield of durum wheat (Triticum durum Desf.) and on available nutrient status in soil. Department of Agronomy, College of Agriculture, Dharwad - 580005 (Kamataka), India. Hisar, India: Gaurav Soci. of Agri. Rese. Info. Centre. Research-on-Crops. 8 (3), 515-519. https://doi.org/10.22438/jeb/38/1/MS-205. 
[3] Atak M, Kaya M, Ciftci C (2004) Effects of zinc and humic acid applications on yield and yield components of durum wheat (Triticum durum L.). Ankara Universities, Ziraat Fakultesi, Tarla Bitkileri Bolumu, DskapAnkara, Turkey. Anadolu. 14 (2), 49-66. https://doi.org/10.20289/euzfd.00621.

[4] Bagci SA, Ekiz H, Yilmaz A, Cakmak I (2007) Effect of zinc deficiency and drought on grain yield of field-grown wheat cultivars in Central Anatolia. Journal of Agronomy and Crop Science 193, 198-206. https://doi.org/10.1111/j.1439-037X.2007.00256.x.

[5] Brown PH, Cakmak I, Zhang Q (1993) Form and function of zinc in plants. Kluwar Academic Publishers. Dordecht, the Netherlands. Robson (Ed). pp. 93-16. https://doi.org/10.1007/978-94-011-0878-2 7 .

[6] Cakmak I, Sari N, Marschner H, Kalayci M, Yilmaz A, Eker S, Gulut KY (1996) Dry matter production and distribution of zinc in bread and durum wheat genotypes differing in zinc efficiency. Plant and Soil 180, 173-181. https://doi.org/10.1007/BF00015300.

[7] Chauhan TM, Javed Ali SP, Singh 1, Singh SB (2014) Effect of Nitrogen and Zinc nutrition on yield, quality and uptake of nutrients by Wheat. Annals of Plant and Soil Research Agra, 2014, 98-10.

[8] Dewal GS and Pareek RG (2004) Effect of phosphorus, sulphur and zinc on growth, yield and nutrient uptake of wheat (Triticum aestivum). Department of Agronomy, S.K.N. College of Agriculture, Jobner, Rajasthan 303 329, India. Indian J. Agron. 49 (3), $160-162$.

[9] El-Majid AA, Knany RE, Fotoh HGA (2000) Effect of foliar application of some micronutrients on wheat yield and quality. Ann. Agric. Sci. 1, 301-313.

[10] Genc Y, McDonald GK, Graham RD (2006) Contribution of different mechanisms to zinc efficiency in bread wheat during early vegetative stage. Plant and Soil 281, 353-367. https://doi.org/10.1007/s11104-005-4725-7.

[11] Goswami (2007) Response of wheat (Triticum aestivum) to nitrogen and zinc application. Ann Agric Res New Series 28 (1), $90-91$.

[12] Grewal HS, Zhonggu L and Graham RD (1997) Influence of subsoil zinc on dry matter production, seed yield and distribution of zinc in oilseed rape genotypes differing in zinc efficiency. Plant and Soil. 192 (2), 181 - 189. https://doi.org/10.1023/A:1004228610138.

[13] Grewal HS, Zhonggu L and Graham RD (1997) Influence of subsoil zinc on dry matter production, seed yield and distribution of zinc in oilseed rape genotypes differing in zinc efficiency. Plant and Soil. 192 (2), 181 - 189. https://doi.org/10.1023/A:1004228610138.

[14] Grotz N and Guerinot ML (2006) Molecular aspects of $\mathrm{Cu}$, Fe and $\mathrm{Zn}$ homeostasis in plants. Biochem. Biophys. Acta. 17(63), 595-608. https://doi.org/10.1016/j.bbamcr.2006.05.014.

[15] Hosseini SM (2006) Zinc and Boron interaction effects on yield, yield components and chemical composition of wheat. The 18th World Congress of Soil Sci.

[16] Islam MR, Islam MS, Jahirhuddin M, Hoque MS (1999) Effect of sulphur, zinc and boron on yield, yield components and nutrients uptake of wheat. Pakistan J. Sci. and Ind. Res. 42 (3), 137-140.

[17] Jain NK and Dahama AK (2007) Effect of phosphorus and zinc on yield, nutrient uptake and quality of wheat (Triticum aestivum). New Delhi, India: Indian Council of Agricultural Research. Indian J. Agric. Sci. 77 (5), 310-313.

[18] Jiang L, Zhang D, Song, F, Zhang X, Shao Y, Li C (2013) Effects of Zinc on Growth and Physiological Characters of Flag Leaf and Grains of Winter Wheat after Anthesis. Adv. J. Food Sci. Technol., 5(5), p. 571-577. https://doi.org/10.19026/ajfst.5.3129.

[19] Kaya Y, Kaya Y, Arisoy RZ, Göcmen A (2002) Variation in grain yield and quality traits of bread wheat genotypes by zinc fertilization. Pakistan Journal of Agronomy 1, 142-144. https://doi.org/10.3923/ja.2002.142.144 .

[20] Kenbaev B and Sade B (2002) Response of field-grown barley cultivars grown on zinc-deficient soil to zinc application. Comm. Soil Sci. Plant Anal. 33, 33-5544. https://doi.org/10.1081/CSS-120002762.

[21] Khan MA, Fuller MP, Baloch FS (2008) Effect of Soil Applied Zinc Sulphate on Wheat (Triticum aestivum L.) Grown on a Calcareous Soil in Pakistan. Cereal Research Communications. 36 (4), pp. 571-582. https://doi.org/10.1556/CRC.36.2008.4.6.

[22] Mahendra S and Yadav BL (2006) Effect of organic materials and zinc on growth and yield of wheat (Triticum aestivum L.) under irrigation with high RSC water. Agricultural Research Station, Fatehpur-Shekhawati, Sikar, India. Haryana Journal of Agronomy. 22 (2), $142-144$.

[23] Modaihsh (1997) Zinc application improved biological yield as well as grain yield of wheat grown on calcareous soils.

[24] Prasad K, Singh BP, Singh RB (1981) Response of Wheat varieties to soil applied Zn. J. Indian Soc. Soil Sci. 29(3), 400-4001.

[25] Ranjbar GA, Bahmaniar MA (2007) Effects of soil and foliar application of Zn fertilizer on yield and growth characteristics of bread wheat (Triticum aestivum L.) cultivars. The University of Mazandaran, Agricultural Campus of Sari, Km 9 Darya Boulevard, Sari, Iran.Asian-Journal-ofPlant-Sciences. 2007; 6(6), 1000-1005. https://doi.org/10.3923/ajps.2007.1000.1005.

[26] Razvi MR, Halepyati AS, Pujari BT, Koppalkar BG (2005) Influence of graded levels of fertilizers applied to green manure and wheat on biomass production of sunnhemp and grain yield of wheat under irrigation. Department of Agronomy, College of Agriculture, Raichur - 584 101, India. Karnataka J. Agric. Sci. 18(1), 4-7.

[27] Riffat S, Samim MK, Mahmud R (2007) Effect of zinc on yield and zinc uptake by wheat on some soils of Bangladesh. J. Soil. Nature. 1(1), 07-14.

[28] Seadh SE, El-Abady MI, El-Ghamry AM, Farouk S (2009) Influence of micronutrient application and nitrogen fertilization on wheat yield, quality of grain and seed. J Bio Sci 9(8), 851-858. https://doi.org/10.3923/jbs.2009.851.858.

[29] Seilsepour M (2007) Study of zinc effects on quantitative and qualitative traits of winter wheat in saline soil condition. Iran Desert Research Center, University of Tehran. BIABAN-. 2006; 11(2), 17-23.

[30] Singh O, Kumar S, Awanish (2012) Productivity and profitability of rice as influence by high fertility leves and their residual effect on wheat. Ind $J$ Agron 57(2), 143-147.

[31] Singh S 2002: Phosphorus, zinc and soil interaction on the uptake of zinc and iron by wheat. Research on Crops 3(2), 363-368.

[32] Singh YP (2004) Effect of nitrogen and zinc on wheat irrigated with alkali water. Annals of Agri- cultural Research 25,233-236.

[33] Soleimani A and Shahrajabian MH (2012) The effects of Fe, Mn and Zn Foliar application on yield, ash and protein percentage of forage sorghum in climatic condition of Esfahan. Int J Bio 4(3), 12-20. https://doi.org/10.5539/ijb.v4n3p92.

[34] Soleimani A and Shahrajabian MH (2012) The effects of Fe, Mn and Zn Foliar application on yield, ash and protein percentage of forage sorghum in climatic condition of Esfahan. Int J Bio 4(3), 12-20. https://doi.org/10.5539/ijb.v4n3p92.

[35] Sundar S and Choudhary SS (2002) Phosphorus, zinc and soil interaction on the uptake of zinc and iron by wheat (Triticum durum). Hisar, India: Gaurav Society of Agricultural Research Information Centre. Res. On Crops. 3 (2), 363-368.

[36] Sundar S, Dave PV, Choudhary SS (2003) Interaction effect of phosphorus, zinc and soil on uptake of phosphorus and copper by wheat and their individual effect on yield. Hyderabad, India: Acharya N.G. Ranga Agricultural University. J. Res. ANGRAU. 31 (3), $117-121$.

[37] UNDP and FAO (1988) Land Resources Appraisal of Bangladesh for Agricultural Development, Report-2. Agro-ecological regions of Bangladesh. BARC/UNDP. New Airport Road, Farmgate, Dhaka-1201. pp. 212-221.

[38] Zaman SMH, Rahman K, Howlar M (1982) Simple Lessons from Biometry. Bangladesh Rice Research Institue, Joydebpur, Gazipur. p-171. 